Article

\title{
Determination of Boron, Phosphorus, and Molybdenum Content in Biosludge Samples by Microwave Plasma Atomic Emission Spectrometry (MP-AES)
}

\author{
Vudagandla Sreenivasulu ${ }^{1}$, Nadavala Siva Kumar ${ }^{2, *}$, Vummiti Dharmendra ${ }^{3}$, \\ Mohammad Asif ${ }^{2}$, Vysetti Balaram ${ }^{4}$, Haung Zhengxu ${ }^{1}$ and Zhou Zhen ${ }^{1}$ \\ 1 Institute of Mass Spectrometry and Atmospheric Environment, Jinan University, \\ No. 601 West Huangpu Avenue, Guangzhou 510632, China; sreenuphdchem@gmail.com (V.S.); \\ hzx126@126.com (H.Z.); zhouzhen@gig.ac.cn (Z.Z.) \\ 2 Department of Chemical Engineering, King Saud University, P.O. Box 800, Riyadh 11421, Saudi Arabia; \\ masif@ksu.edu.sa \\ 3 Agilent Technologies, CP-11, Sector-8, IMT, Manesar, Gurgaon 122 051, India; \\ dharmendra.vummiti@gmail.com \\ 4 Council of Scientific and Industrial Research-National Geophysical Research Institute, \\ Hyderabad 500007, India; balaram1951@yahoo.com \\ * Correspondence: shivanadavala@gmail.com or snadavala@ksu.edu.sa; Tel.: +966-53-722-8108
}

Academic Editors: Samuel B. Adeloju and Jan Yperman

Received: 7 December 2016; Accepted: 3 March 2017; Published: 8 March 2017

\begin{abstract}
A novel analytical method for accurate determination of boron (B), phosphorous (P), and molybdenum (Mo) content in biosludge samples based on a relatively recent analytical technique, microwave plasma atomic emission spectrometry (MP-AES), is developed in the present work. Microwave assisted acid digestion method is utilized to extract $\mathrm{B}, \mathrm{P}$, and Mo from biosludge. To demonstrate the reliability and accuracy of the present MP-AES method, its results are compared with those obtained using two well-established techniques, i.e., flame atomic absorption spectrometry (FAAS) and inductively coupled plasma optical emission spectrometry (ICP-OES). Matrix variation in the MP-AES technique is found to result in minimal changes. Precision and accuracy of the developed method are demonstrated using replicate analyses of certified sewage sludge reference material, EnviroMAT (BE-1). The limit of quantification and detection of B, P, and Mo in the extracts are determined; the linear regression coefficient was greater than 0.998 for all the three techniques. Analytical wavelengths are selected according to the sensitivity and interference effects. The results obtained in this work demonstrate the potential of MP-AES technique for the determination of B, $\mathrm{P}$, and Mo content in biosludge, which achieved lower detection limits, higher accuracy, and better reproducibility as compared to other techniques.
\end{abstract}

Keywords: biosludge; microwave assisted acid digestion; microwave plasma atomic emission spectrometry (MP-AES); boron; phosphorus; molybdenum; inductively coupled plasma optical emission spectrometry (ICP-OES); flame atomic absorption spectrometry (FAAS)

\section{Introduction}

The alarming increase in the world population requires the development of new farmlands to grow sufficient food, which, in turn, necessitates greater use of fertilizers in order to achieve the required food production. In developing countries, the rising prices of chemical fertilizers, coupled with the growing concerns for sustainable soil productivity, have led to a renewed interest in the 
application of organic manure in soil fertility restoration [1]. Organic manure is a vital resource not only for supplying plant nutrients, but also for replenishing the organic matter content of the agricultural soils [2]. Biosludge is a by-product obtained predominantly from secondary wastewater treatment plants. The organic nature of biosludge, which contains plant nutrients and several other useful trace elements, makes it a valuable organic fertilizer for use in farming applications [3-5]. In view of its richness in terms of organic biomass and soil nutrient content, the best management option might be to utilize dried biosludge for agricultural purposes [6]. Owing to its attractive properties, the application of biosludge as a fertilizer has increased from $20 \%$ in 1972 to $55 \%$ in 1997 in USA [7].

Boron is an essential trace element in plants, which plays a key role in controlling calcium metabolism. In case of boron deficiency, the pectin to lipid ratio in plants is shifted in favor of pectin. A disruption of the nucleic acid metabolism, which results in growth disturbances, has also been observed in plants deficient in boron [8]. Moreover, boron is critical for both cell elasticity and the prevention of excessive conversion of sugar to starch. Phosphorus is another essential micronutrient, which mainly affects energy transfer pattern in plants. Its adequate availability stimulates early plant growth. In particular, phosphorus is required for the manufacture of phosphate-containing nucleic acids, adenosine triphosphate (ATP), and membrane lipids. Soils that have been used heavily for agricultural crops are very often deficient in phosphorus. Alkaline and calcareous soils have phosphorus deficiency because of the formation of poorly soluble calcium phosphate minerals. Such phosphorus deficiency in soils can cause shortened plant stem internodes, poor root systems, darkening of leaf tissue, and crop reduction. Similarly, molybdenum is a trace element with a key role in the biochemical processes related to the conversion of atmospheric nitrogen into useful ammonia by bacteria [9]. Its deficiency can eventually result in a diminished number of flowers, severely affecting the development of pollen in the plants [10]. In addition, molybdenum is necessary for the correct functioning of several essential metalloenzymes such as xanthine oxydase, aldehyde oxidase, and sulfite oxidase.

Common methods of chemical analysis of soils and fertilizers for mineral micronutrients include atomic absorption spectrometry (AAS), inductively coupled plasma optical emission spectrometry (ICP-OES), and inductively coupled plasma mass spectrometry (ICP-MS) [11-13]. In addition to the AOAC (Association of Analytical Communities) official method 965.09, AAS has been widely utilized for the quantification of various elements in plant nutrient sources [14]. The limitations of AAS with regard to sensitivity, accuracy, simplicity, and freedom from interferences have resulted in the increased use of emission-based techniques such as ICP-OES for the determination of elements in the soils and related materials [15]. Commonly employed excitation sources for emission techniques include flames, electric arcs, and plasmas. In particular, argon plasma-based systems have been utilized extensively for both qualitative and quantitative analyses over the last 40 years [16].

In this context, the microwave plasma atomic emission spectrometry (MP-AES) introduced recently by Hammer represents a very important and useful addition to the existing array of analytical techniques [17]. MP-AES is a multi-element technique that offers better detection limits over a wider analytical working range than FAAS. Unlike previous microwave-induced plasma (MIP) sources, which coupled energy from the microwave electric field, this technique uses a novel magnetically excited emission source coupled to an emission spectrometer. The resultant plasma shape allows easy entrainment of the wet sample aerosol into the core of the plasma, similar to that produced by a conventional ICP nebulizer and a spray chamber. The first commercial MP-AES instruments were introduced in 2011. In our earlier studies, this technique was utilized successfully for the generation of precise data required for geochemical investigations and mineral exploration studies of precious metals in rock and ore materials $[18,19]$. In another study, an attempt was made to demonstrate the potential of MP-AES for environmental studies [20]. Several other studies have employed MP-AES for the determination of trace elements such as $\mathrm{Cu}, \mathrm{Fe}, \mathrm{Mn}$, and $\mathrm{Zn}$ in animal feed and fertilizers [21], gasoline and ethanol [22], petroleum crude oil [23], diesel and biodiesel [24], and biofortified yeast analysis [25]. Different procedures have been proposed for determining the content of metallic species 
in biosludge samples [26]. However, due to the complexity of biosludge matrices, time-consuming sample preparation and content determination procedures are typically required. In the present study, an attempt is made to develop a rapid method for the determination of B, P, and Mo content in biosludge samples utilizing the MP-AES technique. Microwave assisted acid digestion system is utilized for sample preparation and its results are compared to those determined using conventional ICP-OES and FAAS methods. Finally, the potential for the application of MP-AES in the analyses of similar materials is discussed and compared with those of FAAS and ICP-OES.

\section{Materials and Methods}

\subsection{Instrumentation}

A MP-AES instrument (Model: 4100, Agilent Inc., Santa Clara, CA, USA) was used in all trace element determinations. The sample introduction system consisted of solvent-resistant tubing, a double-pass cyclonic chamber, and an inert flow blurring nebulizer (OneNeb). The operating parameters are presented in Table 1. Details of the instrumentation have been described in previous publications [19,20]. Nitrogen gas was obtained from a generator connected to a simple air compressor. Instrumental parameters such as the nebulizer gas pressure, the viewing position (i.e., the analytical observation zone in the plasma), and the background correction were optimized automatically and individually for each element using the instrument software (MP Expert, Agilent Technologies, Santa Clara, CA, USA). The microwave-assisted acid digestion technique was utilized for the preparation of samples using the microwave assisted acid digestion system, CEM MARS 5. No further sample preparation was required and no modifiers or ionization buffers were added. For the purpose of comparison, Inductively Coupled Plasma-Optical Emission Spectrometer (Model: 720ES, ICP-OES, Agilent Inc., Santa Clara, CA, USA) with an ICP Expert II software (Agilent Technologies, Mulgrave, Victoria, Australia) and Fast Sequential-Atomic Absorption Spectrometer (Model: 280FS, FS-AAS, Agilent Inc., Santa Clara, CA, USA) with SpectrAA Pro software (Mulgrave, Victoria, Australia) were used for the determination of $\mathrm{B}, \mathrm{P}$, and Mo content in biosludge samples.

Table 1. Operating parameters of microwave plasma atomic emission spectrometry (MP-AES), inductively coupled plasma optical emission spectrometry (ICP-OES), and flame atomic absorption spectrometry (FAAS).

\begin{tabular}{|c|c|c|}
\hline \multirow{14}{*}{$\begin{array}{l}\text { Agilent } 4100 \text { Microwave } \\
\text { Plasma-Atomic Emission } \\
\text { Spectrometer (MP-AES) } \\
\text { with } 4107 \text { Nitrogen } \\
\text { Generator }\end{array}$} & \multicolumn{2}{|l|}{ Plasma Conditions } \\
\hline & Plasma gas & $\begin{array}{l}\text { Nitrogen (by using an Air Compressor and a } \\
\text { Nitrogen Generator) }\end{array}$ \\
\hline & Power of Magnetron out put & $1 \mathrm{~kW}$ \\
\hline & \multicolumn{2}{|l|}{ Gas Flows } \\
\hline & Plasma Gas flow-Nitrogen & $20 \mathrm{~L} / \mathrm{min}$ \\
\hline & Intermediate flow-Nitrogen & $1.1 \mathrm{~L} / \mathrm{min}$ \\
\hline & Pre-optics protection (POP) gas-Air & $25 \mathrm{~L} / \mathrm{min}$ \\
\hline & Nebulizer pressure & $140-240 \mathrm{kPa}$ (Optimize for each group of elements) \\
\hline & Nebulizer & $\begin{array}{l}\text { OneNeb inert concentric for HF and high Total } \\
\text { Dissolved Solid (TDS) solutions }\end{array}$ \\
\hline & Spray chamber & Double pass glass cyclonic \\
\hline & Solution uptake & $1.4 \mathrm{~mL} / \mathrm{min}$ (pumped) \\
\hline & Pump tubing & $1.02 \mathrm{~mm}$ i.d. PVC (Polyvinyl Chloride) \\
\hline & Plasma Torch & Quartz torch \\
\hline & Plasma Viewing & Axial \\
\hline
\end{tabular}


Table 1. Cont.

\begin{tabular}{ll}
\hline \multicolumn{2}{l}{ Data Acquisition Parameters } \\
\cline { 2 - 2 } Sample Uptake delay (s) & 8 \\
\hline Stabilization time (s) & 15 \\
\hline Rinse time (s) & 30 \\
\hline Read time (s) & 5 \\
\hline No. of replicates & 3 \\
\hline Background correction & Auto or FLIC (Fast Linear Interference Correction) \\
\hline Optical system & $\begin{array}{l}\text { Czerny-Turner design Monochromator with 600 mm } \\
\text { focal length and fixed entrance slit }\end{array}$ \\
\hline Detector & $\begin{array}{l}\text { Back thinned solid state charge-coupled device } \\
\text { (CCD) detector (532 } \times 128 \text { pixels) }\end{array}$ \\
\hline Analytes (Wavelengths) & B (249.677 nm), P (213.618 nm) and Mo (379.825 nm) \\
\hline
\end{tabular}

\subsection{Reagents and Materials}

All chemicals used were of analytical reagent quality. $\mathrm{HNO}_{3}(69 \%), \mathrm{HCl}(30 \%)$, and $\mathrm{HClO}_{4}$ $(60 \%-62 \%)$ were procured from Merck (Darmstadt, Germany). Individual standard stock solutions of $1000 \mathrm{mg} / \mathrm{L}$ of B, P, and Mo (SPEX Certiprep, Inc., Metuchem, NJ, USA) were utilized. For calibrations, standards of appropriate dilutions were prepared using the individual stock standard solutions. Ultrapure water with a resistivity of $18.2 \mathrm{M} \Omega / \mathrm{cm}$ was obtained using the Milli-Q system (Millipore, Billerica, MA, USA). Microwave assisted acid digestion system (CEM, Corp. MARS Express, Matthews, NC, USA) was utilized. A total of three biosludge samples were collected locally from Institute of Atmospheric Environmental Safety and Pollution Control Department, Delhi, India. A certified sewage sludge reference material (CRM) EnviroMAT ${ }^{\mathrm{TM}}$ (BE-1), which is similar in composition and applications to biosludge was utilized in this study for procedure validation.

\subsection{Sample Preparation}

The CEM Mars 5 closed-vessel, microwave assisted acid digestion system (Matthews, NC, USA) was used to extract the elements of interest from the sewage sludge and biosludge (city compost) samples [27]. Three different types of digestion were applied based on the recommendations reported in the United States Environmental Protection Agency (USEPA) methods 3050, 3051, and 3051A [28-30]. Biosludge and CRM samples (fully dried) were prepared by accurately weighing $0.5 \mathrm{~g}$ of each sample (in triplicate) into a Teflon/PFA-lined microwave assisted acid digestion vessels and a different composition of an acid mixture was added: Method A (USEPA 3050) is a hot plate digestion method based on using $1 \mathrm{~g}$ of sample with multiple steps of the addition of acid. In the first step, $10 \mathrm{~mL}$ of 1:1 nitric acid was digested for a few minutes followed by the addition of another $5 \mathrm{~mL}$ of concentrated nitric acid until completely digested. Finally, another $5 \mathrm{~mL}$ of HCL (30\%) was added. Method B (USEPA 3051 ) is a microwave assisted acid digestion method based on $0.5 \mathrm{~g}$ of sample with the addition of $10 \mathrm{~mL}$ of nitric acid. Method C (USEPA 3051A) is also a microwave assisted acid digestion method based on using $0.5 \mathrm{~g}$ of sample with $9 \mathrm{~mL}$ of nitric acid and $3 \mathrm{~mL}$ of hydrochloric acid. Following digestion, the solutions were allowed to cool to room temperature, transferred to $50 \mathrm{~mL}$ volumetric flasks, made to the required volume with $18.2 \mathrm{M} \Omega / \mathrm{cm}$ deionized water, and labeled. The microwave assisted acid digestion program settings are provided in Table 2. 
Table 2. Operating conditions for microwave assisted acid digestion system.

\begin{tabular}{cccccc}
\hline Stage & \multicolumn{2}{c}{ Power $(\mathbf{W})$} & Ramp $(\mathbf{m i n})$ & Temp. $\left({ }^{\circ} \mathbf{C}\right)$ & Holding Time (min) \\
\hline Step & Max $(w)$ & $\%$ & & & \\
\hline 1 & 800 & 70 & 15 & 180 & 10 \\
2 & 800 & 80 & 15 & 190 & 10 \\
3 & 800 & 100 & 10 & 220 & 5 \\
\hline
\end{tabular}

\section{Experimental Section}

The wavelengths used in the analysis of B, P, and Mo are listed in Table 3 for each instrument. The instrumental limit of detection (LOD) and the limit of quantification (LOQ) (Equations (1) and (2) were determined using the standard deviation obtained with synthetic solutions, which were prepared by fortifying blank solution with known concentrations $(0.1 \mu \mathrm{g} / \mathrm{mL}$ for $\mathrm{B}$ and Mo, and $1.0 \mu \mathrm{g} / \mathrm{mL}$ for P), as follows:

$$
\begin{gathered}
\mathrm{LOD}=3 \times S \\
\mathrm{LOQ}=10 \times S
\end{gathered}
$$

where $S$ represents the standard deviation of nine replicates $(n=9)$.

Table 3. Characteristic wavelength (nm) for MP-AES, ICP-OES, and FAAS.

\begin{tabular}{cccc}
\hline Elements & MP-AES & ICP-OES & FAAS \\
\hline B & 249.677 & 249.677 & 249.8 \\
P & 213.618 & 213.618 & 213.6 \\
Mo & 379.825 & 379.825 & 313.3 \\
\hline
\end{tabular}

The calibration data of B, P, and Mo were generated for each instrument and are shown in (Table 4). The concentration of each element was determined when the correlation coefficient was greater than 0.998. The extract from the original sample was shared between three instruments, MP-AES, ICP-OES, and FAAS, in order to eliminate variations in sample preparation and extractions procedures in the determination of $\mathrm{B}, \mathrm{P}$, and Mo content. The results of analyses yielded two sets of data. One-way ANOVA analysis was performed to evaluate the statistical difference within the data sets.

Table 4. Linearity data for boron, phosphorous and molybdenum using MP-AES and ICP-OES.

\begin{tabular}{ccccccccc}
\hline \multirow{2}{*}{ S. No. } & \multirow{2}{*}{ Elements } & $\begin{array}{c}\text { Linearity } \\
\text { Range (mg/L) }\end{array}$ & \multicolumn{2}{c}{ Slope } & \multicolumn{2}{c}{ Y-Intercept } & \multicolumn{2}{c}{$\begin{array}{c}\text { Correlation } \\
\text { Coefficient }\left(\boldsymbol{r}^{2}\right)\end{array}$} \\
\cline { 4 - 9 } & & & MP-AES & ICP-OES & MP-AES & ICP-OES & MP-AES & ICP-OES \\
\hline 1 & $\mathrm{~B}$ & $0.0-2.0$ & 6962 & 9642 & 10.63 & 16.28 & 0.999 & 0.999 \\
2 & $\mathrm{P}$ & $0.0-200.0$ & 116 & 208.6 & 84.06 & 95.8 & 0.998 & 0.999 \\
3 & Mo & $0.0-1.0$ & 6075 & 7297 & 17.70 & 18.7 & 0.999 & 0.998 \\
\hline
\end{tabular}

\section{Results and Discussion}

In recent years, MP-AES has been slowly emerging as one of the most powerful and popular analytical tools for the analysis of various materials. The mechanism of MP-AES is very similar to that of ICP-OES. The only difference between these two techniques is the ionization/atomization source. MP-AES uses nitrogen plasma instead of argon plasma, which is used in ICP-OES. Nitrogen plasma is sustained by a lower pressure microwave source that operates at atmospheric pressure. Nitrogen is non-flammable and cost-efficient, and can be easily sourced from the atmospheric air using a compressor. Moreover, nitrogen plasma temperature is lower (5000 K) compared to argon plasma (8000-10,000 K) [22]. As a result of this temperature difference, spectral interferences are less 
significant and the majority of elements remain in the atomic state, thereby resulting in simpler atomic emission spectral lines than those obtained with argon plasma [19].

\subsection{Accuracy, Precision, and Detection Limits}

The analytical results obtained for the determination of B, P, and Mo content in three different biosludge samples and a certified sewage sludge sample, run in duplicate (i.e., each element was determined six times), are presented in Tables 5 and 6 . Overall, the accuracy obtained for the certified reference sample using method USEPA 3051A was $90 \%-94 \%$, with a precision of $<2 \%$ Relative Standard Deviation. More consistent results were obtained for the elements present at higher concentrations. The obtained precisions were less than 3\% RSD for the three real analytical biosludge samples. The error deviation determined for both MP-AES and ICP-OES techniques was $<6.5 \%$. The LODs obtained for B, P, and Mo using all the three methods are presented in Table 7. Clearly, MP-AES and ICP-OES are much better than FAAS. Moreover, the LODs for P and Mo in case of MP-AES are smaller than corresponding values for ICP-OES.

\subsection{MP-AES Spectra of $B, P$, and Mo}

Identical wavelengths were used ( $249.677 \mathrm{~nm}$ for $\mathrm{B}, 213.618 \mathrm{~nm}$ for $\mathrm{P}$, and $379.825 \mathrm{~nm}$ for Mo) in the measurements of emission signals for both MP-AES and ICP-OES. For the determination of the analyte concentration, a direct comparison of the respective signals in the linear range was followed rather than the conventional method, which relies on rational extrapolations [19]. Analysis of the experimental results revealed that MP-AES provides a wider linear range in the calibrations for B, $\mathrm{P}$, and Mo than FAAS and ICP-OES. These observations demonstrate that MP-AES is comparable to ICP-OES in multi elemental determination and a more convenient method than FAAS because of the advantages already described.

\subsection{Calibrations}

When calibrations were performed in different concentration ranges for $\mathrm{B}, \mathrm{P}$, and $\mathrm{Mo}$, the response in each experiment was non-linear at all wavelengths examined, with a higher response at higher concentrations. Nevertheless, the software's rational model for the calibration afforded an excellent fit $\left(r^{2}>0.998\right)$. The slope, intercept and correlation coefficient values were represented in Table 4.

\subsection{Effect of Different Digestion Methods of USEPA 3050, 3051, and 3051A on Analytical Results}

In order to understand the efficiencies and variations in the recovery of $\mathrm{B}, \mathrm{P}$, and Mo achieved using different USEPA digestion procedures (3050, 3051, and 3051A), a comparative study was undertaken using a sewage sludge certified reference material, CRM EnviroMAT ${ }^{\mathrm{TM}}$ (BE-1), followed by sample analysis using MP-AES. The elements B, P, and Mo were recovered at $89.9 \%, 90.9 \%$, and $92.2 \%$ using Method 3050; 84.8\%, 92.2\% and 87.5\% with Method 3051; and 92.9\%, 93.7\%, and 90.6\% using Method 3051A, respectively. Yields obtained with Method 3051A are much closer to the certified values (Table 5) than those determined using other two methods. Moreover, the precision in the case of Method 3051A was always below 2\% RSD, which is substantially better than corresponding values for other two methods, i.e., 3050 and 3051. In fact, a similar study was carried out by Chen and Ma (1998) to compare the effectiveness of four USEPA digestion methods for trace metal analysis using certified Florida soil reference materials [31]. These workers also observed that Method 3051A was more effective as compared to Method 3050 and Method 3051. 
Table 5. Results (in mg/kg) of the analysis of Standard Reference Material (SRM)-sewage sludge EnviroMAT (BE-1) using different United States Environmental Protection Agency (USEPA) digestion methods.

\begin{tabular}{|c|c|c|c|c|c|c|c|c|c|c|c|c|c|}
\hline \multirow[t]{2}{*}{ Elements } & \multicolumn{3}{|c|}{ Method 3050} & \multicolumn{4}{|c|}{ Method 3051} & \multicolumn{4}{|c|}{ Method 3051A } & \multicolumn{2}{|c|}{$\begin{array}{l}\text { SRM-Sewage Sludge } \\
\text { EnviroMAT (BE-1) }\end{array}$} \\
\hline & $\begin{array}{l}\text { Concentration, } \\
(\mathrm{mg} / \mathrm{kg})\end{array}$ & $\begin{array}{c}\text { Accuracy, } \\
\%\end{array}$ & $\begin{array}{l}\text { Precision, } \\
\text { \% RSD }\end{array}$ & $\begin{array}{l}\text { Concentration, } \\
(\mathrm{mg} / \mathrm{kg})\end{array}$ & $\begin{array}{c}\text { Accuracy, } \\
\%\end{array}$ & $\begin{array}{l}\text { Precision, } \\
\% \text { RSD }\end{array}$ & $\begin{array}{c}\text { Bias } \\
1\end{array}$ & $\begin{array}{c}\text { Concentration, } \\
(\mathrm{mg} / \mathrm{kg})\end{array}$ & $\begin{array}{c}\text { Accuracy, } \\
\%\end{array}$ & $\begin{array}{l}\text { Precision, } \\
\% \text { RSD }\end{array}$ & $\begin{array}{c}\text { Bias } \\
2\end{array}$ & $\begin{array}{c}\text { Consensus } \\
\text { Value, }(\mathrm{mg} / \mathrm{kg})\end{array}$ & $\begin{array}{l}\text { Confidence } \\
\text { Interval }\end{array}$ \\
\hline B & $8.9 \pm 0.5$ & 89.9 & 2.8 & $8.4 \pm 0.6$ & 84.8 & 2.9 & -5.6 & $9.2 \pm 0.4$ & 92.9 & 1.3 & 3.4 & $(9.9)$ & - \\
\hline $\mathrm{P}$ & $27,105.0 \pm 45$ & 90.9 & 3.4 & $27,505.0 \pm 65$ & 92.2 & 2.1 & 1.5 & $27,946.0 \pm 70$ & 93.7 & 0.8 & 3.1 & 29,826 & $27,906-31,746$ \\
\hline Mo & $5.9 \pm 0.2$ & 92.2 & 6.2 & $5.6 \pm 0.4$ & 87.5 & 2.6 & -5.1 & $5.8 \pm 0.2$ & 90.6 & 1.8 & -1.7 & 6.4 & $5.9-6.9$ \\
\hline
\end{tabular}

Table 6. Comparison of B, P, and Mo in analytical samples digested by USEPA Method 3051A and analyzed by using MP-AES \& ICP-OES.

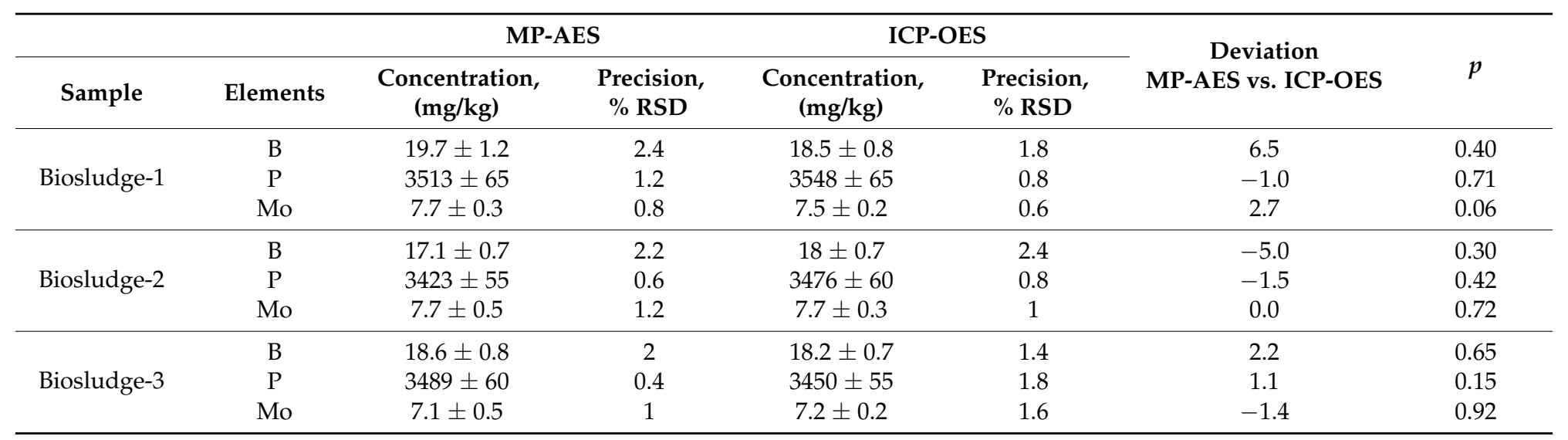


Table 7. Comparison of limit of detection (LOD) in mg/L of different techniques.

\begin{tabular}{cccc}
\hline Elements & MP-AES & ICP-OES & FAAS \\
\hline B & 0.001 & 0.001 & 1 \\
P & 0.025 & 0.030 & 50 \\
Mo & 0.002 & 0.003 & 0.03 \\
\hline
\end{tabular}

\subsection{Comparison of the Analytical Performance of MP-AES, ICP-OES, and FAAS}

Three different biosludge samples and one sample of certified sewage sludge reference material were digested using the USEPA method 3051A and the resulting sample solutions were analyzed by MP-AES and ICP-OES, and flame-AAS. The analytical results are provided in Table 6 and the graphical representation of the same results is shown in Figure 1. The analysis showed that the FAAS failed to detect B, P, and Mo at low levels of concentrations. The detection limits of MP-AES are much better than those of FAAS, and are much closer to those obtained using ICP-OES, even in the determination of other elements such as $\mathrm{Fe}, \mathrm{Zn}, \mathrm{Mn}$, and $\mathrm{Cu}$. The one-way statistical analysis of variance (ANOVA) performed on the results obtained using MP-AES and ICP-OES yielded a $p$-value greater than 0.05 , indicating that there were no statistically significant differences between the two techniques [21].

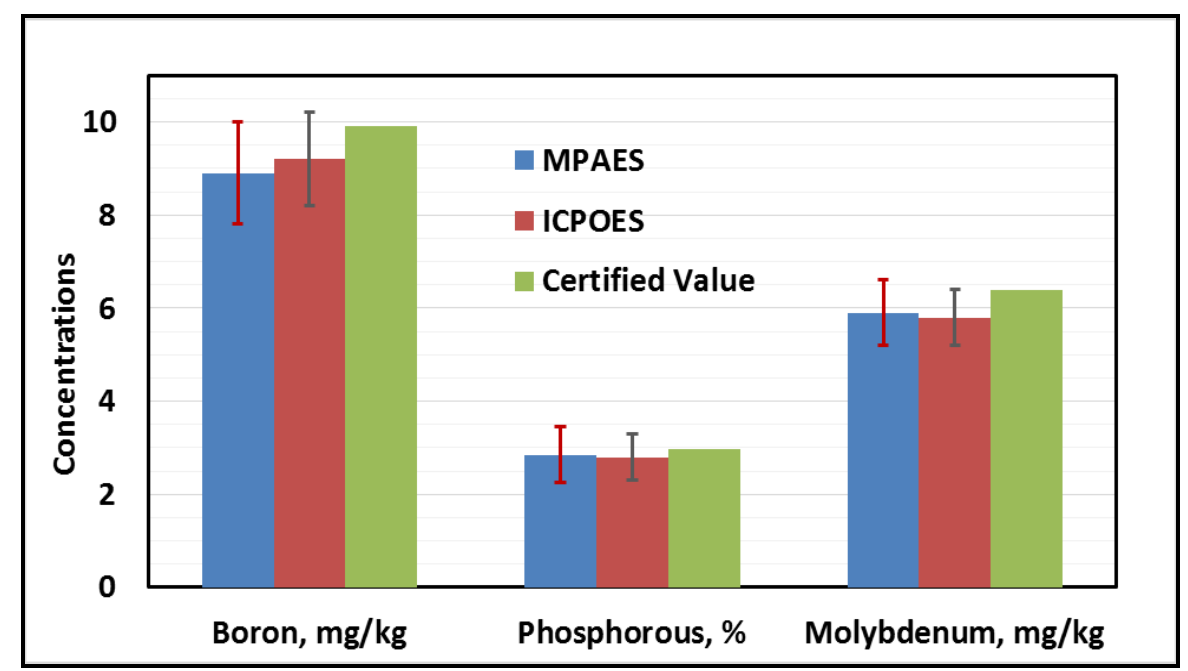

Figure 1. Agreement between certified values and the values obtained in this study by MP-AES and ICP-OES for B, P and Mo in SRM-Sewage Sludge EnviroMAT (BE-1).

\section{Conclusions}

Most of the soil testing labs, especially for agriculture purposes, cannot afford expensive analytical instruments in developing countries. MP-AES is a relatively cheaper multi-element instrumental technique. The results of this study indicate that MP-AES can be a cost-effective analytical tool for the routine and direct analysis of biosludge samples for critical micronutrients. The methodology developed in this work is simple and efficient, and provides high sample throughput. ANOVA tests demonstrated that there are no significant differences between the analytical results obtained using MP-AES and ICP-OES for the determination of $\mathrm{B}, \mathrm{P}$, and Mo content in biosludge samples. Compared to ICP-OES, MP-AES is more economical because of its lower cost and the use of an easily sourceable nitrogen gas, which can be generated using an air compressor and a nitrogen generator. In addition, LODs and LOQs determined for B, P, and Mo using MP-AES are comparable to the well-established ICP-OES technique, and are significantly superior to those obtained with FAAS. In fact, analyses of B, $\mathrm{P}$, and Mo, which are difficult using FAAS, can be carried out using the MP-AES technique in a single run. In addition, this technique has several advantages, such as the possibility of deployment even in 
remote locations where access to gases such as argon can be difficult. This study reveals that MP-AES is cost-effective as well as accurate for determining the content of $\mathrm{B}, \mathrm{P}$, and Mo in biosludge samples and is a convenient replacement for FAAS and ICP-OES. The procedure developed in this work will be beneficial for analytical applications in the future.

Acknowledgments: Mohammad Asif appreciates the support of the Deanship of Scientific Research at King Saud University for the Prolific Research Group PRG-1437-31. One of the authors (Vysetti Balaram) would like to thank CSIR, New Delhi, India, for financial support in the form of the Emeritus Scientist Scheme.

Author Contributions: Vudagandla Sreenivasulu, Vysetti Balaram and Vummiti Dharmendra conceived, designed and supervised the experiments and put together the initial draft of the paper; Vummiti Dharmendra performed the experiments; Haung Zhengxu and Zhou Zhen carried out the literature review; Mohammad Asif and Nadavala Siva Kumar analyzed the data, finalized the paper and Nadavala Siva Kumar was the main corresponding author during the review process.

Conflicts of Interest: The authors declare no conflict of interest.

\section{References}

1. Sankaram, A. Soil fertility management for reconciling sustainability with productivity. J. Indian Soc. Soil Sci. 1996, 44, 593-600.

2. Reddy, D.D.A.; Subbarao, A.; Rupa, T.R. Effects of continuous use of cattle manure and fertilizer phosphorus on crop yields and soil organic phosphorus in a vertisol. Bioresour. Technol. 2000, 75, 113-118. [CrossRef]

3. Matthews, P. Agricultural and other land uses. In Sludge into Biosolids: Processing, Disposal and Utilization; Spinosa, L., Vesilind, P.A., Eds.; IWA Publishing: London, UK, 2001; pp. 41-73.

4. Okuno, N. Production of usable materials. In Sludge into Biosolids: Processing, Disposal, Utilization; Spinosa, L., Vesilind, P.A., Eds.; IWA Publishing: London, UK, 2001; pp. 147-163.

5. Tay, J.H.; Show, K.Y. Utilization of municipal wastewater sludge as building and construction materials. Resour. Conserv. Recycl. 1992, 6, 191-204. [CrossRef]

6. Wen-Tien, T. An Analysis of waste management policies on utilizing biosludge as material Resources in Taiwan. Sustainability 2012, 4, 1879-1887.

7. Vesilind, P.A.; Spinosa, L. Production and regulations. In Sludge into Biosolids: Processing, Disposal, Utilization; Spinosa, L., Vesilind, P.A., Eds.; IWA Publishing: London, UK, 2001; pp. 3-18.

8. Sarica, D.Y.; Ertas, N. Flow injection Analysis for Boron Determination by Using Methyl Borate Generation and Flame Atomic Emission Spectrometry. Turk. J. Chem. 2001, 25, 305-310.

9. Farooq, M.; Wahid, A.; Siddique, K.H.M. Micronutrient application through seed treatments-A review. J. Soil Sci. Plant Nutr. 2012, 12, 125-142. [CrossRef]

10. Kaiser, B.N.; Kate, L.G.; Joanne, N.B.; Phillips, T.; Tyerman, D. The role of molybdenum in agricultural plant production. Ann. Bot. 2005, 96, 745-754. [CrossRef] [PubMed]

11. Wang, X.; Lasztity, A.; Viczian, M.; Israel, Y.; Barnes, R.M. Inductively coupled plasma spectrometry in the study of childhood soil ingestion. J. Anal. Atom. Spectrom. 1989, 4, 727-735. [CrossRef]

12. Balaram, V. Recent trends in the instrumental analysis of rare earth elements in geological and Industrial Materials. Trends Anal. Chem. 1996, 15, 475-486. [CrossRef]

13. Bader, N.R.; Zimmermann, B. Sample preparation for atomic spectroscopic analysis: An overview. Adv. Appl. Sci. Res. 2012, 3, 1733-1737.

14. Oliveira, S.R.; Jose, A.G.N.; Joaquim, A.N.; Bradley, T.J. Determination of macro and micronutrients in plant leaves by high-resolution continuum source flame atomic absorption spectrometry combining instrumental and sample preparation strategies. Spectrochim. Acta B At. Spectrosc. 2010, 65, 316-320. [CrossRef]

15. Balaram, V.; Anjaiah, K.V.; Reddy, M.R.P. A comparative study on the trace and rare earth element analysis of an Indian Polymetallic Nodule Reference Sample by Inductively Coupled Plasma Atomic Emission Spectrometry and Inductively Coupled Plasma Mass Spectrometry. Analyst. 1995, 120, 1401-1406. [CrossRef]

16. Boss, C.B.; Fredeen, K.J. Concepts, Instrumentation and Techniques in Inductively Coupled Plasma Optical Emission Spectrometry; Perkin-Elmer Corporation: Waltham, MA, USA, 1997; p. 125.

17. Hammer, M.R. A magnetically excited microwave plasma source for atomic emission spectroscopy with performance approaching that of the inductively coupled plasma. Spectrochim. Acta B 2008, 63, 456-464. [CrossRef] 
18. Balaram, V.; Dharmendra, V.; Roy, P.; Taylor, C.; Kar, P.; Kumar Raju, A.; Krishnaiah, A. Determination of Precious Metals in Rocks and Ores by Microwave Plasma-Atomic Emission Spectrometry (MP-AES) for geochemical prospecting. Curr. Sci. 2013, 104, 1207-1215.

19. Balaram, V.; Dharmendra, V.; Roy, P.; Taylor, C.; Kamala, C.T.; Satyanarayanan, M.; Kar, P.; Subramanyam, K.S.V.; Kumar Raju, A.; Krishnaiah, A. Analysis of geochemical samples by microwave plasma-AES. At. Spectrosc. 2014, 35, 65-78.

20. Kamala, C.T.; Balaram, V.; Dharmendra, V.; Satyanarayanan, M.; Subramanyam, K.S.V.; Krishnaiah, A. Application of microwave plasma atomic emission spectrometry (MP-AES) for environmental monitoring of industrially contaminated sites in Hyderabad city. Environ. Monit. Assess. 2014, 186, 7097-7113. [CrossRef] [PubMed]

21. Li, W.; Simmons, P.; Shrader, D.; Herrman, T.J.; Dai, S.Y. Microwave plasma-atomic emission spectroscopy as a tool for the determination of copper, iron, manganese and zinc in animal feed and fertilizer. Talanta 2013, 112, 43-48. [CrossRef] [PubMed]

22. Donati, G.L.; Amais, R.S.; Schiavo, D.; Nobrega, J.A.N. Determination of Cr, Ni, Pb and V in gasoline and ethanol fuel by microwave plasma optical emission spectrometry. J. Anal. At. Spectrom. 2013, $28,755$. [CrossRef]

23. Nelson, J.; Gilleland, G.; Poirier, L.; Leong, D.; Hajdu, P.; Lopez Linares, F. Elemental analysis of crude oils using microwave plasma atomic emission spectrometry. Energy Fuels 2015, 29, 5587-5594. [CrossRef]

24. Amais, R.S.; Donati, G.L.; Schiavo, D.; Nobrega, J.A. A simple dilute-and-shoot procedure for Si determination in diesel and biodiesel by microwave-induced plasma optical emission spectrometry. Microchem. J. 2013, 106, 318-322. [CrossRef]

25. Barrientos, E.Y.; Wroberl, K.; Torres Guzman, J.C.; Corrales Escobosa, A.R.; Wrobel, K. Determinatio of SeMet and Se(IV) in biofortified yeast by ion-pair reversed phase liquid chromatography-hydride generation-microwave induced nitrogen plasma atomic emission spectrometry (HPLC-HG-MP-AES). J. Anal. At. Spectrom. 2016, 31, 203-211. [CrossRef]

26. Khalid, U.; Sarfaraz, K.; Said, G.; Muhammad, U.; Niamatullah, Muhammad A.K.; Shad, K.K. Sewage Sludge: An Important biological resource for sustainable agriculture and its environmental implications. Am. J. Plant Sci. 2012, 3, 1708-1721.

27. Balaram, V. Microwave dissolution techniques for the analysis of geological materials by ICP-MS. Curr. Sci. 1997, 73, 1019-1023.

28. Association of Official Agricultural Chemists International. Association of Official Agricultural Chemists International. AOAC International method 985.01: Metals and other elements in plants and pet foods. In Official Methods of Analysis of AOAC International, 18th ed.; AOAC International: Gaithersburg, MD, USA, 2005.

29. United States Environmental Protection Agency. United States Environmental Protection Agency. USEPA-Test method for evaluating solid waste. In Laboratory Manual Physical/Chemical Methods, SW 846, 3rd ed.; U.S. Government Printing Office: Washington, DC, USA, 1995; Volume 1A.

30. United States Environmental Protection Agency (USEPA). Method 3051A-Microwave Assisted Acid Digestion of Sediments, Sludges, Soils And Oils; United States Environmental Protection Agency: Washington, DC, USA, 1998.

31. Chen, M.; Ma, L.Q. Comparison of four USEPA digestion methods for trace metal analysis using certified and Florida soils. J. Environ. Qual. 1998, 27, 1294-1300. [CrossRef]

(C) 2017 by the authors. Licensee MDPI, Basel, Switzerland. This article is an open access article distributed under the terms and conditions of the Creative Commons Attribution (CC BY) license (http:/ / creativecommons.org/licenses/by/4.0/). 